\title{
Identification and characterization of Pseudomonas syringae pv. mori affecting white mulberry (Morus alba) in Poland
}

\author{
Krzysztof Krawczyk • Malgorzata Lochyńska $(\mathbb{D}$
}

Accepted: 8 July 2020 /Published online: 15 July 2020

(C) The Author(s) 2020

\begin{abstract}
The white mulberry (Morus alba L.) is particularly valued in Asia and Europe because its leaves serve as fodder for the mulberry silkworm (Bombyx mori L.) in the production of raw silk (sericulture). However, the health of silkworm caterpillars producing silk fibres, and the quality of their cocoons depend strongly on fodder quality. Moreover, this plant is also valuable in the food and pharmaceutical industries, where high-quality herbal material is required. In one of the Polish mulberry plantations, trees with chlorotic, angular leaf spots and blotches were observed. The disease multiplied in spring in humid conditions and spread to developing blossoms and leaves. Leaves were collected during two growing seasons (2017-2018) from 18-year-old trees cultivated at the Experimental Farm of the Institute of Natural Fibres and Medicinal Plants in Petkowo, Poland (52 $\left.12^{\prime} 40^{\prime \prime} \mathrm{N} 17^{\circ} 15^{\prime} 31^{\prime \prime} \mathrm{E}\right)$. Leaf lesions exhibited bacterial streaming, and bacterial colonies were readily isolated on tryptic soy agar.
\end{abstract}

Electronic supplementary material The online version of this article (https://doi.org/10.1007/s10658-020-02074-x) contains supplementary material, which is available to authorized users.

K. Krawczyk $(\bowtie)$

Department of Molecular Biology and Biotechnology, Institute of Plant Protection-National Research Institute, Władysława

Węgorka 20, 60-318 Poznań, Poland

e-mail: k.krawczyk222@gmail.com

M. Łochyńska

Department of Silkworms Breeding and Mulberry Cultivation, Institute of Natural Fibres and Medicinal Plants, Wojska Polskiego 71B, 60-630 Poznań, Poland
Biochemical (Biolog Gen III system v. 2.8.0), molecular (16S rDNA and gyrB genes), and pathogenicity testing in the greenhouse identified the causal agent as Pseudomonas syringae. This bacterial species was the most abundant in each of the sample tested. To our knowledge this is the first description and characterization of $P$. syringae affecting mulberry trees not only in Poland but throughout Europe. Our aim was to point out the importance of plant diseases caused by bacteria. This finding serves as a warning for the phytosanitary services in Europe and for the sericulture industry that a new disease threat has appeared for European mulberry crops.

Keywords Pseudomonas syringae $\cdot$ Mulberry $\cdot$ Morus alba . Plant pathogenic bacteria $\cdot$ First report $\cdot$ Bacterial blight

\section{Introduction}

The white mulberry (Morus alba L.) is particularly valued in Asia and Europe because its leaves serve as fodder for larvae of the mulberry silkworm (Bombyx mori L.) in the production of raw silk (Barbour et al. 2008). Sericulture is a very important sector of the silk industry, but the health of silkworm caterpillars producing silk fibres, and the quality of their cocoons, depend strongly on fodder quality (Chen and Lu 2018). Any impairment of mulberry leaves caused by either microbial pests or plant protection chemicals affects negatively on the resulting silk quality (Chairman et al. 2012). 
Moreover, mulberry leaves are very valuable in the food and pharmaceutical industries, where high-quality herbal material is required.

Mulberry trees have no special soil requirements and endure drought stress quite well. Moreover, this species is affected by a low number of natural pest, which limits the use of plant protection products and supports organic farming. Among mulberry arthropod pests are sapsucking species, defoliators and borers belonging to the Lepidoptera, Hemiptera, Coleoptera, Thysanoptera, Orthoptera, Isoptera and mites (Rahmathulla and Sathyanarayana 2015; Wulandari et al. 2018). However mulberry may be affected also by various phytopathogenic agents such as nematodes (e.g., Meloidogyne incognita) (Muthulakshmi et al. 2010), phytoplasmas (e.g., mulberry dwarf phytoplasma) (Dai et al. 1997), fungi causing leaf-spots (e.g., Cercospora spp. and Mycosphaerella mori) (Barbour et al. 2008), and bacteria (Lou et al. 2011; Sahin et al. 1999; Wang et al. 2008).

Among bacterial diseases, bacterial blight caused by Pseudomonas syringae is a common disease of mulberry that has been reported from various agroclimatic conditions in Australia, Iran, South Africa, America, Indonesia, India and Pakistan (Akhtar and Sarwar 1988; Baharuddin 1997; Gupta et al. 1995; Wulandari et al. 2018). Infection by $P$. syringae can cause death of seedlings, a significant problem in mulberry nurseries (Hinrichs-Berger 2004), and reduces fruit yield and quality of mature trees (Bultreys and Kaluzna 2010). In general, studies of Pseudomonas strains from fruit trees are hampered by the fact that a host often supports multiple species (Mansfield et al. 2012). The taxonomic relationships of such fruit tree strains have been assessed in several genetic studies, leading to the designation of new pathovars (Kennely et al. 2007). At present $P$. syringae has been divided into over 50 pathovars, which are pathogenic to over 180 plant species, including woody plants, crops and grasses (Kaluzna et al. 2010; Khezri and Mohammadi 2018).

In Europe, $P$. syringae on fruit trees such as some fruits, hazelnut or citrus has been reported from France, the United Kingdom, Germany, Lithuania and Poland, however all reports concerned stone fruit trees, hazelnut, and citrus blast (Kaluzna et al. 2010). Currently, Pseudomonas syringae affecting mulberry trees has not been recorded in Europe, although it was reported in other parts of the world as P. syringae pv. mori, the most important bacterial disease of mulberry, causing bacterial blight (Baharuddin 1997; Gupta et al. 1995; Sahin et al. 1999; Takahashi 1980).
In 2017 and 2018, in one of the Polish mulberry plantations, trees with leaf symptoms resembling bacterial blight were observed. The aim of this study was to isolate, identify, and characterize the causal agent of the white mulberry disease using biochemical, molecular, and pathogenicity testing.

\section{Materials and methods}

\section{Plant material}

Symptomatic leaves of the Polish white mulberry cultivar Zolwinska wielkolistna were collected during two growing seasons, 2017 and 2018. The leaves were taken from 18-year-old trees cultivated at the Experimental Farm of the Institute of Natural Fibres and Medicinal Plants in Petkowo (52 $\left.12^{\prime} 40^{\prime \prime} \mathrm{N} 17^{\circ} 15^{\prime} 31^{\prime \prime} \mathrm{E}\right)$, and sent to the laboratory for the investigation. Four samples were collected, each consisting of 10 leaves collected from trees displaying chlorotic, angular leaf spots and blotches.

\section{Pathogen isolation}

The leaves were washed in tap water and surfacedisinfested by washing in sodium hypochlorite $(10 \%)$ for $1 \mathrm{~min}$, a second washing in ethyl alcohol (70\%) for $1 \mathrm{~min}$, followed by triple washing in sterile distilled water. Next the leaves were homogenized in sterile physiological saline $(0.9 \% \mathrm{NaCl})$ and investigated in the following manner. First, before homogenization, the symptomatic tissue was investigated under a light microscope $(40 \mathrm{X})$ to check for bacterial streaming. The second test was electron microscopy screening for the presence of virus particles (Golding et al. 2016). Third, an aliquot of the homogenized leaf tissue was plated on potato dextrose agar (PDA; Sigma Aldrich Ltd.) to check for the presence of fungi, and lastly, the homogenized tissue was plated on tryptic soy agar (TSA; Sigma Aldrich Ltd.) to grow potentially present plant pathogenic bacteria.

The incubation lasted for five days on TSA medium at $27^{\circ} \mathrm{C}$ to account for potentially slow-growing plant pathogenic bacteria. After incubation, a series of purification streaks was performed until a pure culture of each grown morphotype was obtained. The purity of each tested colony was verified on the basis of colony morphology and with Gram staining under the light microscope. 
Pathogen identification

Both biochemical and molecular methods were used to identify the bacteria. For biochemical identification, the Biolog's Gen III system (database v. 2.8.0) (BIOLOG Inc. Hayward, CA) was used, according to the manufacturer's instructions. The molecular identification was based on the analysis of partial sequences of $16 \mathrm{~S}$ rDNA and gyrB genes. Bacterial genomic DNA was isolated using a CTAB protocol (García-González et al. 2018), and the extract was kept at $-20{ }^{\circ} \mathrm{C}$ for further experiments. For PCR amplification, the following universal bacterial 16S rDNA primers were used: 16S04 (AACTCAAA GGAATTGACGG) (Gerischer 2008) and pH 2 (AAG GAG GTG ATC CAG CCG CA) (Edwards et al. 1989). For the gyrB gene partial nucleotide sequence amplification, the $1480 \mathrm{~F} / 2242 \mathrm{R}$ primer pair (Bonasera et al. 2014) was used. PCR products of $\sim 1400$ bp for $16 \mathrm{~S}$ rDNA and 900 bp for gyrB were obtained using a touch-down PCR protocol (Korbie and Mattick 2008). The expected size amplicons were extracted from the agarose gel using Wizard SV Gel and PCR Clean-Up System (Promega, Madison, WI), and sequenced (Genomed S.A., Warsaw, Poland). The obtained sequences were verified against the GenBank database (BLAST), aligned, and the consensus sequences were submitted to the GenBank database to obtain accession numbers. For obtained DNA sequences, multiple sequence alignments were performed using ClustalW software, and a phylogenetic tree was constructed in Mega X software using the maximum likelihood method (bootstrapping 1000 repeats) (Kumar et al. 2018). The tree was rooted with Pectobacterium carotovorum 16S rDNA (NR_025316.1) and gyrB (FJ652727.1) sequences. The computed dendrograms contain all accession numbers and the names of the strains used in the analysis.

To confirm our identification results, the previously designed and published Pseudomonas syringae speciesspecific PCR primer pair (D21/D22) was used, as described (Schaad et al. 2001). Obtained amplicons of the expected size were analysed, sequenced, and submitted to the GenBank database as described above for the $16 \mathrm{~S}$ rDNA and gyrB sequences.

\section{Pathogenicity tests}

All bacterial isolates obtained were tested in a pathogenicity test in greenhouse conditions (temperature 20$25^{\circ} \mathrm{C}$, humidity $50-80 \%$ ) to confirm Koch's postulates. Each isolate was tested on five healthy mulberry seedlings of the Zolwinska wielkolistna cultivar. The plants were inoculated with an aqueous bacterial suspension $\left(10^{6}-10^{7} \mathrm{cfu} / \mathrm{ml}\right)$ applied under high pressure on both sides of the leaves with a compressor sprayer, after wounding the leaves by abrasion with carborundum (EPPO Bulletin 2006). After inoculation, each plant was kept in a humid chamber for $72 \mathrm{~h}$, and then in the greenhouse until symptom development. After incubation, symptomatic plants were subjected to reisolation to confirm Koch's postulates. All reisolated strains were investigated as described above. Sterile distilled water sprayed instead of the bacterial suspension was used as a negative control, and an aqueous suspension $\left(10^{6}-\right.$ $10^{7} \mathrm{cfu} / \mathrm{ml}$ ) of Pseudomonas syringae pv. syringae 2238, from the Institute of Plant Protection Bank of Pathogens collection was used as a positive control.

Since strains of $P$. syringae are often present as epiphytes on leaves (Arnold and Preston 2019), before performing the pathogenicity tests the leaves of the healthy mulberry plants to be used were washed with sterile distilled water and the suspension was plated on King's B medium (Sigma Aldrich Ltd.) to ensure that the concentration of epiphytic Pseudomonas was uniform among plants.

\section{Results}

Symptoms description

The original symptoms observed on mulberry trees involved light-chlorotic lesions spreading on the leaf surface (Fig. 1). With time, the lesions increased in size from between 2 and $3 \mathrm{~mm}$ to $8-10 \mathrm{~mm}$, their margins turned brown, and the centre of the lesions turn necrotic.

Pathogen identification

Biochemical identification

No virus particles were observed by electron microscopy. Also no fungal growth was observed on PDA medium. Hence, the presence of viruses and fungi as potential disease causal agents was excluded. Further tests were directed towards detection and identification of bacteria.

The examination of fresh, symptomatic leaf tissue under the light microscope showed a slight streaming of bacterial ooze. This feature is characteristic for most of the plant bacterial pathogens. 

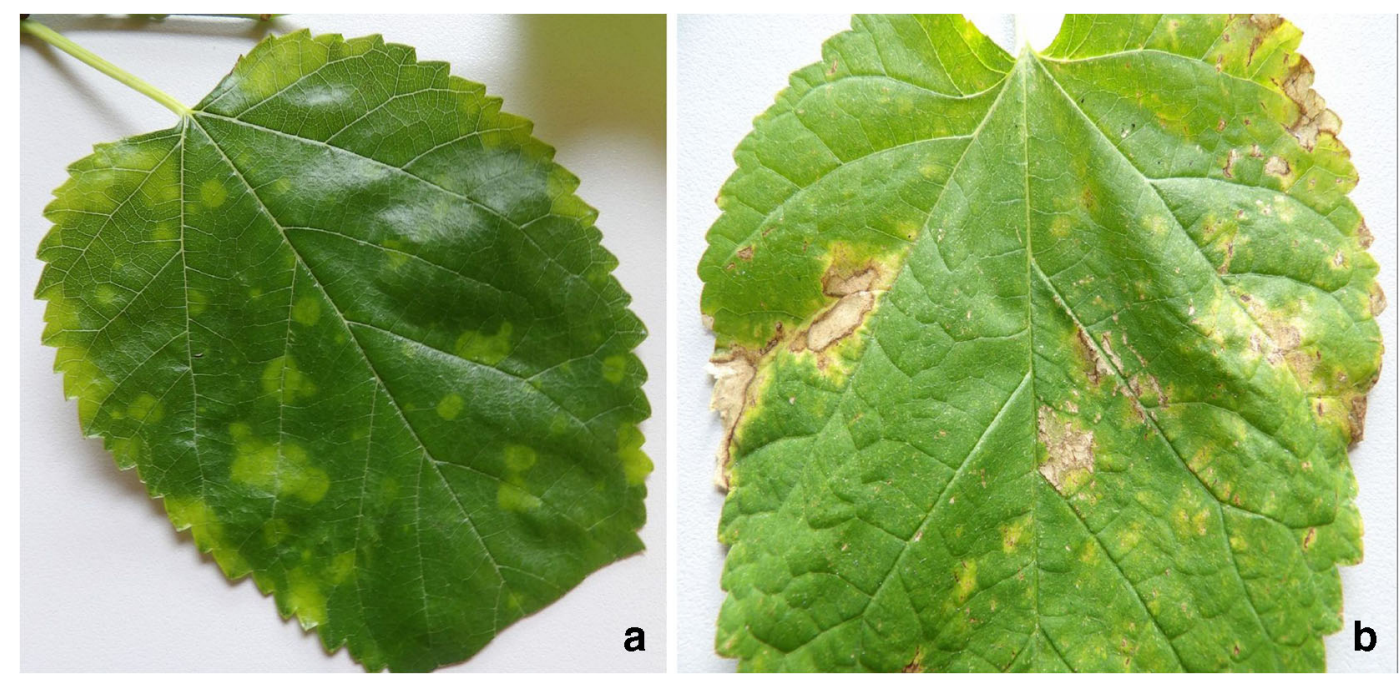

Fig. 1 Leaves of the symptomatic mulberry plants. A - whole leaf - early symptoms, B - close-up - late symptoms

In total, 22 isolates were obtained during the two growing seasons. In 2017, 12 isolates were obtained, and 10 isolates were obtained in 2018. The pure cultures of all 22 bacterial isolates were subjected to biochemical identification using Biolog's Gen III system. As a result the following bacterial species were tentatively identified: Pseudomonas syringae (four isolates), P. fluorescens (1), Pantoea agglomerans (4), Serratia liquefaciens (1), Rothia mucilaginosa (1), Curtobacterium luteum (1), Cellulomonas cellasea (2), Bacillus ruris (1), and seven isolates resulted as "no identification", indicating that they are not included in Biolog's database (v. 2.8.0) that contains 1568 bacterial species comprising 258 plant pathogenic bacteria, including Pseudomonas syringae. The most abundant species in each of the four leaf samples tested, was $P$. syringae. Moreover all mulberry plants that developed symptoms in the pathogenicity tests turned out to comprise this pathogen (Table 1).

\section{Molecular identification}

Molecular identification based on partial nucleotide sequences of the $16 \mathrm{~S}$ rRNA and $g y r \mathrm{~B}$ genes confirmed this identification result (Table 1). The detailed results of BLAST verification of the obtained pathogen sequences are presented in the supplement (Table S1 and Table S2). A sequence identity matrix analysis of obtained 16S rDNA and gyrB sequences was performed (Tables 2, 3), and dendrograms of those sequences were generated using the maximum likelihood method and involving nucleotide sequences of both genes of the four detected P. syringae strains (Ma001, Ma011, Ma013, and $\mathrm{Ma} 020$ ), the three $P$. syringae strains obtained from reisolation (Ma011-1, Ma020-1, and Ma020-3), and other Pseudomonas plant-pathogenic and nonpathogenic environmental species sequences derived from GenBank. The accession numbers of all analysed sequences are included in the dendrograms (Figs. 2, 3).

Additionally, pathogen identification was verified by using and sequencing the products of the PCR primer pair D21/D22, which was published as $P$. syringae-specific, (Schaad et al. 2001). All tested pathogen samples resulted in P. syringae, confirming the identification based on $16 \mathrm{~S}$ rDNA and gyrB sequencing (Table 1 and Table S3).

The percentage DNA identity between the sequences we obtained from the Polish mulberry isolates and the GenBank derived sequences of $16 \mathrm{~S}$ rRNA and gyrB genes of $P$. amygdali pv. mori (syn. $P$. syringae pv. mori) is high, 99,2-100\%, for $16 \mathrm{~S}$ rRNA (Table 2) and $99-99,6 \%$ for gry $\mathrm{B}$ (Table 3 ). This suggests that we detected P. syringae pv. mori, and that this is the actual causal agent of the disease, because most often, when a new disease emerges, the pathogen is clonal and at least all gyr B sequences would be expected to be identical or almost identical to each other, which is what we observed (Table 2, 3, Figs. 2, 3).

\section{Pathogenicity test}

The symptomatic leaves collected from the field were homogenized and all obtained bacterial isolates were used for inoculation of mulberry seedlings in the pathogenicity test, as described above. All symptom-causing isolates 
Table 1 Bacterial isolates obtained from the collected mulberry leave samples in Poland, 2017-2018. nt - not tested

\begin{tabular}{|c|c|c|c|c|c|c|c|}
\hline No & $\begin{array}{l}\text { Strain } \\
\text { tested }\end{array}$ & $\begin{array}{l}\text { Sample } \\
\text { no. / Season }\end{array}$ & $\begin{array}{l}\text { Biolog Gen III } \\
\text { identification result }\end{array}$ & $\begin{array}{l}\text { Mulberry } \\
\text { pathogenic } \\
\text { (Yes / no) }\end{array}$ & $\begin{array}{l}\text { 16S rDNA } \\
\text { sequencing result } \\
\text { (GenBank } \\
\text { accession } \\
\text { number) }\end{array}$ & $\begin{array}{l}\text { gyrB sequencing } \\
\text { result } \\
\text { (GenBank } \\
\text { accession } \\
\text { number) }\end{array}$ & $\begin{array}{l}\text { P. syringae } \mathrm{PCR} \\
\text { species specific } \\
\text { primers (D21/D22) }\end{array}$ \\
\hline 1 & $\mathrm{Ma001}$ & $\mathrm{M} 1 / 2017$ & Pseudomonas syringae & yes & $\begin{array}{l}\text { P. syringae } \\
\text { (MN636727) }\end{array}$ & $\begin{array}{l}\text { P. syringae } \\
(\mathrm{MT} 008015)\end{array}$ & $\begin{array}{l}\text { P. syringae } \\
\text { (MN646774) }\end{array}$ \\
\hline 2 & $\mathrm{Ma002}$ & M1/2017 & Pantoea agglomerans & no & nt & nt & $\mathrm{nt}$ \\
\hline 3 & $\mathrm{Ma003}$ & M1/2017 & Serratia liquefaciens & no & $\mathrm{nt}$ & $\mathrm{nt}$ & $\mathrm{nt}$ \\
\hline 4 & $\mathrm{Ma004}$ & M1/2017 & Pantoea agglomerans & no & nt & $\mathrm{nt}$ & $\mathrm{nt}$ \\
\hline 5 & $\mathrm{Ma} 005$ & M1/2017 & Rothia mucilaginosa & no & $\mathrm{nt}$ & $\mathrm{nt}$ & $\mathrm{nt}$ \\
\hline 6 & $\mathrm{Ma006}$ & $\mathrm{M} 1 / 2017$ & Curtobacterium luteum & no & nt & $\mathrm{nt}$ & $\mathrm{nt}$ \\
\hline 7 & $\mathrm{Ma} 007$ & M2/2017 & Bacillus ruris & no & $\mathrm{nt}$ & $\mathrm{nt}$ & $\mathrm{nt}$ \\
\hline 8 & $\mathrm{Ma008}$ & M2/2017 & Pseudomonas fluorescens & no & nt & nt & $\mathrm{nt}$ \\
\hline 9 & $\mathrm{Ma009}$ & $\mathrm{M} 2 / 2017$ & Cellulomonas cellasea & no & nt & $\mathrm{nt}$ & $\mathrm{nt}$ \\
\hline 10 & $\mathrm{Ma} 010$ & $\mathrm{M} 2 / 2017$ & Cellulomonas cellasea & no & nt & $\mathrm{nt}$ & $\mathrm{nt}$ \\
\hline 11 & Ma011 & M2/2017 & Pseudomonas syringae & yes & $\begin{array}{l}\text { P. syringae } \\
\text { (MN636728) }\end{array}$ & $\begin{array}{l}\text { P. syringae } \\
\text { (MT008016) }\end{array}$ & $\begin{array}{l}\text { P. syringae } \\
\text { (MN646775) }\end{array}$ \\
\hline 12 & Ma012 & M2/2017 & No identification & no & $\mathrm{nt}$ & $\mathrm{nt}$ & nt \\
\hline 13 & $\mathrm{Ma} 013$ & $\mathrm{M} 1 / 2018$ & Pseudomonas syringae & yes & $\begin{array}{l}\text { P. syringae } \\
\text { (MN636729) }\end{array}$ & $\begin{array}{l}\text { P. syringae } \\
(\mathrm{MT} 008017)\end{array}$ & $\begin{array}{l}\text { P. syringae } \\
(\mathrm{MN} 646776)\end{array}$ \\
\hline 14 & Ma014 & M1/2018 & No identification & no & $\mathrm{nt}$ & $\mathrm{nt}$ & $\mathrm{nt}$ \\
\hline 15 & $\mathrm{Ma} 015$ & $\mathrm{M} 1 / 2018$ & No identification & no & nt & nt & $\mathrm{nt}$ \\
\hline 16 & $\mathrm{Ma016}$ & M1/2018 & No identification & no & nt & nt & $\mathrm{nt}$ \\
\hline 17 & Ma017 & M2/2018 & No identification & no & nt & $\mathrm{nt}$ & $\mathrm{nt}$ \\
\hline 18 & $\mathrm{Ma018}$ & $\mathrm{M} 2 / 2018$ & No identification & no & nt & $\mathrm{nt}$ & $\mathrm{nt}$ \\
\hline 19 & Ma019 & M2/2018 & Pantoea agglomerans & no & $\mathrm{nt}$ & $\mathrm{nt}$ & $\mathrm{nt}$ \\
\hline 20 & $\mathrm{Ma} 020$ & M2/2018 & Pseudomonas syringae & yes & $\begin{array}{l}\text { P. syringae } \\
\text { (MN636730) }\end{array}$ & $\begin{array}{l}\text { P. syringae } \\
\text { (MT008018) }\end{array}$ & $\begin{array}{l}\text { P. syringae } \\
\text { (MN646777) }\end{array}$ \\
\hline 21 & $\mathrm{Ma} 022$ & M2/2018 & Pantoea agglomerans & no & $\mathrm{nt}$ & nt & $\mathrm{nt}$ \\
\hline 22 & $\mathrm{Ma} 022$ & $\mathrm{M} 2 / 2018$ & No identification & no & nt & $\mathrm{nt}$ & $\mathrm{nt}$ \\
\hline \multicolumn{8}{|c|}{ Reisolation - Selected strains } \\
\hline 23 & Ma011-1 & M2/2017 & Pseudomonas syringae & yes & $\begin{array}{l}\text { P. syringae } \\
(\mathrm{MN} 636731)\end{array}$ & $\begin{array}{l}\text { P. syringae } \\
\text { (MT008019) }\end{array}$ & $\begin{array}{l}\text { P. syringae } \\
\text { (MN646778) }\end{array}$ \\
\hline 24 & $\mathrm{Ma} 020-1$ & M2/2018 & Pseudomonas syringae & yes & $\begin{array}{l}\text { P. syringae } \\
\text { (MN636732) }\end{array}$ & $\begin{array}{l}\text { P. syringae } \\
\text { (MT008020) }\end{array}$ & $\begin{array}{l}\text { P. syringae } \\
\text { (MN646779) }\end{array}$ \\
\hline 25 & $\mathrm{Ma} 020-3$ & M2/2018 & Pseudomonas syringae & yes & $\begin{array}{l}\text { P. syringae } \\
(\mathrm{MN} 636733)\end{array}$ & $\begin{array}{l}\text { P. syringae } \\
\text { (MT008021) }\end{array}$ & $\begin{array}{l}\text { P. syringae } \\
(\mathrm{MN} 646780)\end{array}$ \\
\hline
\end{tabular}

turned out to be $P$. syringae (Table 1). After artificial inoculation, disease symptoms were observed for four out of 22 isolates tested; in each tested leaf sample (M12/2017 and M1-M2/2018, Table 1), the most abundant isolate was $P$. syringae. The symptoms developed within 7-10 days, whereas the negative control showed no disease symptoms. Indeed, the inoculation method used, spraying the leaves with bacterial suspension of the four isolates under pressure, resulted in obtaining disease symptoms resembling those observed originally in the infected trees (Fig. 4). The results obtained in the pathogenicity test allow to conclude that $P$. syringae is the actual causal agent of the disease of mulberry trees in Poland.

The observed pathogenicity of Polish $P$. syringae strains was much higher than the control $P$. syringae pv. syringae 2238 strain (Fig. 4). 
Table 2 Result of sequence identity matrix (SIM) analysis of the 16S rDNA sequences of bacterial isolates from mulberry obtained in this study compared with the reference sequence of Pseudomonas amygdali pv. mori (GenBank no AB001446)

\begin{tabular}{lllllllll}
\hline & Ma001 & Ma011 & Ma013 & Ma020 & Ma011-1 & Ma020-1 & $\begin{array}{c}\text { Ma020-3 } \\
\text { Pam }\end{array}$ \\
\hline Ma001 & ID & 0,996 & 0,994 & 0,994 & 0,992 & 0,992 & 0,992 \\
Ma011 & 0,996 & ID & 0,998 & 0,998 & 0,996 & 0,996 & 0,996 & 0,992 \\
Ma013 & 0,994 & 0,998 & ID & 1000 & 0,998 & 0,998 & 0,998 \\
Ma020 & 0,994 & 0,998 & 1000 & ID & 0,998 & 0,998 & 0,998 & 0,996 \\
Ma011-1 & 0,992 & 0,996 & 0,998 & 0,998 & ID & 1000 & 1000 & 1000 \\
Ma020-1 & 0,992 & 0,996 & 0,998 & 0,998 & 1000 & ID & 1000 \\
Ma020-3 & 0,992 & 0,996 & 0,998 & 0,998 & 1000 & 1000 & ID & 1000 \\
AB001446 & 0,992 & 0,996 & 0,998 & 0,998 & 1000 & 1000 & 1000 \\
Pam & & & & & & & ID \\
\hline
\end{tabular}

This observation supports the thesis that Polish strains belong to $P$. syringae pv. mori, and that this is the causal agent of the disease since it elicits more severe symptoms than the $P$. syringae subsp. syringae strain used as the positive control. We are aware that using a high enough concentration of $P$. syringae and high pressure spraying under conditions conducive to disease, many $P$. syringae strains can cause some disease symptoms on several plant species even if they cannot cause disease on that plant under field conditions. Therefore, the result observed for the positive and negative controls is very important and supports our thesis.

\section{Discussion}

Pseudomonas syringae is an example of a plant pathogenic bacterium with significant impact, because of its basic biology and its impact on the agricultural economy. P. syringae is considered the first of the top 10 most important plant pathogenic bacteria in plant pathology (Mansfield et al. 2012). This pathogen has an extremely wide host range. That is why it is still debatable if the term "pathovar" is best description of $P$. syringae or whether we are dealing with one extremely versatile and adaptive single bacterial species (Mansfield et al. 2012). Its economic importance has been studied for a century, such as in case of bacterial canker of stone fruits. The results of such studies are extremely important because they inform epidemiological studies and the role of epiphytic stages in the life cycles of plant pathogenic bacteria (Bultreys and Kaluzna 2010).

$P$. syringae affects mulberry trees. Indeed, bacterial blight of mulberry caused by $P$. syringae pv. mori has been recorded in India, Pakistan, South Africa, Australia, Indonesia, and Turkey so far (Akhtar and Sarwar

Table 3 Result of sequence identity matrix (SIM) analysis of the partial gyrB gene DNA sequences of bacterial isolates from mulberry obtained in this study compared with the two reference sequences of Pseudomonas amygdali pv. mori (GenBank no AB016355, AB016347)

\begin{tabular}{llllllllll}
\hline & Ma001 & Ma011 & Ma013 & Ma020 & Ma011-1 & Ma020-1 & Ma020-3 & AB016355 & AB016347 \\
\hline Ma001 & ID & 0,994 & 0,978 & 0,991 & 0,993 & 0,996 & 0,996 & 0,993 & 0,990 \\
Ma011 & 0,994 & ID & 0,983 & 0,993 & 0,994 & 0,998 & 0,998 & 0,995 & 0,991 \\
Ma013 & 0,978 & 0,983 & ID & 0,980 & 0,978 & 0,981 & 0,981 & 0,985 & 0,981 \\
Ma020 & 0,991 & 0,993 & 0,980 & ID & 0,993 & 0,994 & 0,994 & 0,991 & 0,988 \\
Ma011-1 & 0,993 & 0,994 & 0,978 & 0,993 & ID & 0,996 & 0,996 & 0,993 & 0,990 \\
Ma020-1 & 0,996 & 0,998 & 0,981 & 0,994 & 0,996 & ID & 1000 & 0,996 & 0,993 \\
Ma020-3 & 0,996 & 0,998 & 0,981 & 0,994 & 0,996 & 1000 & ID & 0,996 & 0,993 \\
AB016355 & 0,993 & 0,995 & 0,985 & 0,991 & 0,993 & 0,996 & 0,996 & ID & 0,996 \\
AB016347 & 0,990 & 0,991 & 0,981 & 0,988 & 0,990 & 0,993 & 0,993 & 0,996 & ID \\
\hline
\end{tabular}




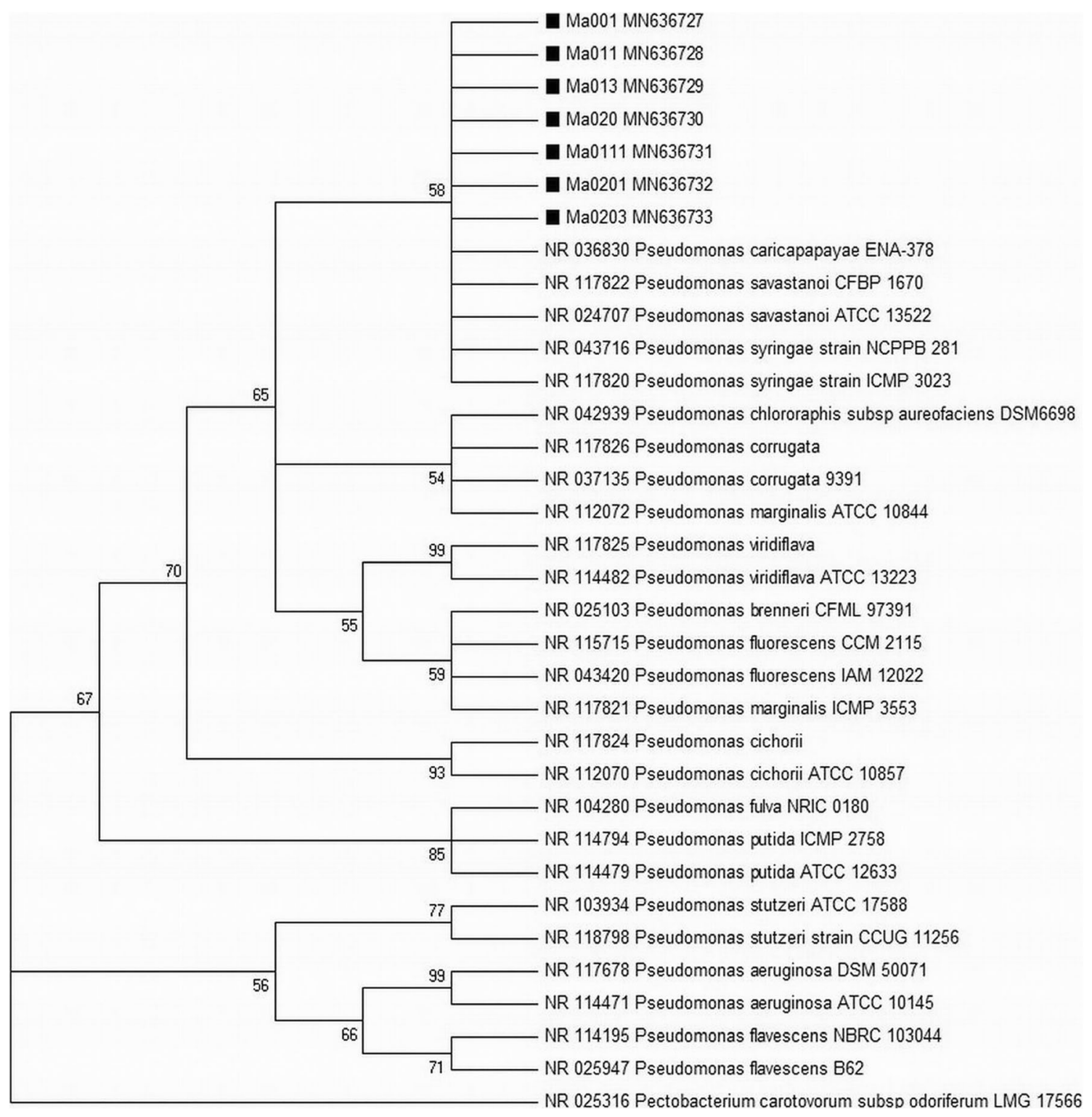

Fig. 2 Results of maximum likelihood analysis of the 16S rRNA gene partial nucleotide sequences of the obtained isolates, in relation to both plant-pathogenic and non-pathogenic Pseudomonas species. The Pectobacterium carotovorum sequence (NR 025316.1) was used as outgroup to root the tree. The Polish $P$. syringae isolates are marked with black squares. BioEdit

1988; Gupta et al. 1995; Sahin et al. 1999; Wulandari et al. 2018). The symptoms of the disease described in the literature were identical with those presented in our study. The symptomatic leaves were covered with irregular spots with yellow haloes, which later changed into necrotic dark brown spots. Moreover, the incidence was much higher during the rainy season (Baharuddin 1997), comparably with observations in Poland. (v7.0.5.3) and Mega X software was used for multiple sequence alignments and the phylogenetic analysis, based on ClustalW and maximum likelihood algorithms implemented with BioEdit and Mega programs, respectively. Bootstrap values of 1000 pseudoreplicates were used for phylogenetic comparisons

Similar to other plant hosts, the infection with $P$. syringae pv. mori has severe consequences for mulberry crops. The quality of mulberry leaves is of special importance because the leaves are used as a fodder for the silkworm B. mori, which has been domesticated for centuries and therefore is very sensitive to changes in breeding conditions and fodder. It is obvious that infection of mulberry leaves influences the growth and 


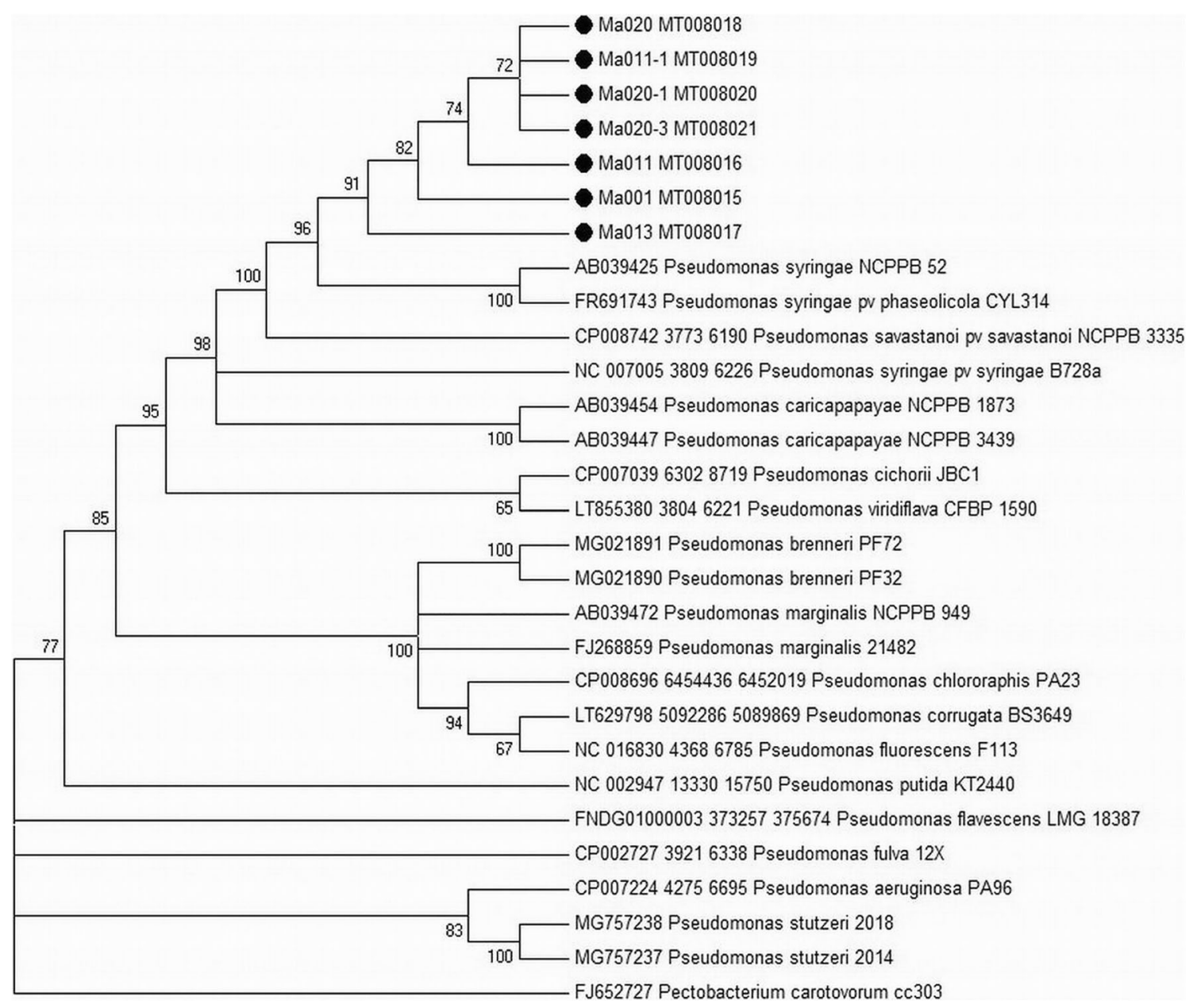

Fig. 3 Results of maximum likelihood analysis of the gyrB gene partial nucleotide sequences of the obtained isolates, in relation to both plant-pathogenic and non-pathogenic Pseudomonas species. The Pectobacterium carotovorum sequence (FJ652727.1) was used as outgroup to root the tree. The Polish $P$. syringae isolates are marked with black circles. BioEdit (v7.0.5.3) and Mega X

development of silkworm larvae and ultimately the economical cocoon parameters (Y. Chen et al. 2018). That is why the proper breeding conditions of silkworms and the dietary components of mulberry leaves are so important for silk production, immune responses and resistance to pathogen infection of this valuable insect.

The systematic position of $P$. syringae pv. mori is continuously changing. Multilocus sequence analyses confirm there are multiple species and pathovars of P. syringae (Dillon et al. 2019; Yamamoto et al. 2000). According to recent studies involving DNA relatedness and ribotyping the following pathovars of P. syringae are included in Pseudomonas amygdali, namely tabaci, lachrymans, phaseolicola, mori, among software was used for multiple sequence alignments and phylogenetic analysis, based on ClustalW and neighbour joining algorithms implemented with BioEdit and Mega programs, respectively. Bootstrap values of 1000 pseudoreplicates were used for phylogenetic comparisons

others (Haeyoung et al. 2015; Yamamoto et al. 2000); however, both species names are still accepted.

Despite extensive studies on management of $P$. syringae, effective means of controlling this pathogen have not been established. Several methods of protection against $P$. syringae have been tested on mulberry. For example, soil treatment with formaldehyde was tested against bacterial canker of white mulberry seedlings. Despite some efficiency, it turned out that such treated mulberry seedbeds should not be located near older mulberry trees because of its phytotoxic influence (Barbour et al. 2008). Also, attempts of developing an antimicrobial antioxidant from the plant source to treat plant pathogenic bacteria such as $P$. syringae have been made. Aqueous 

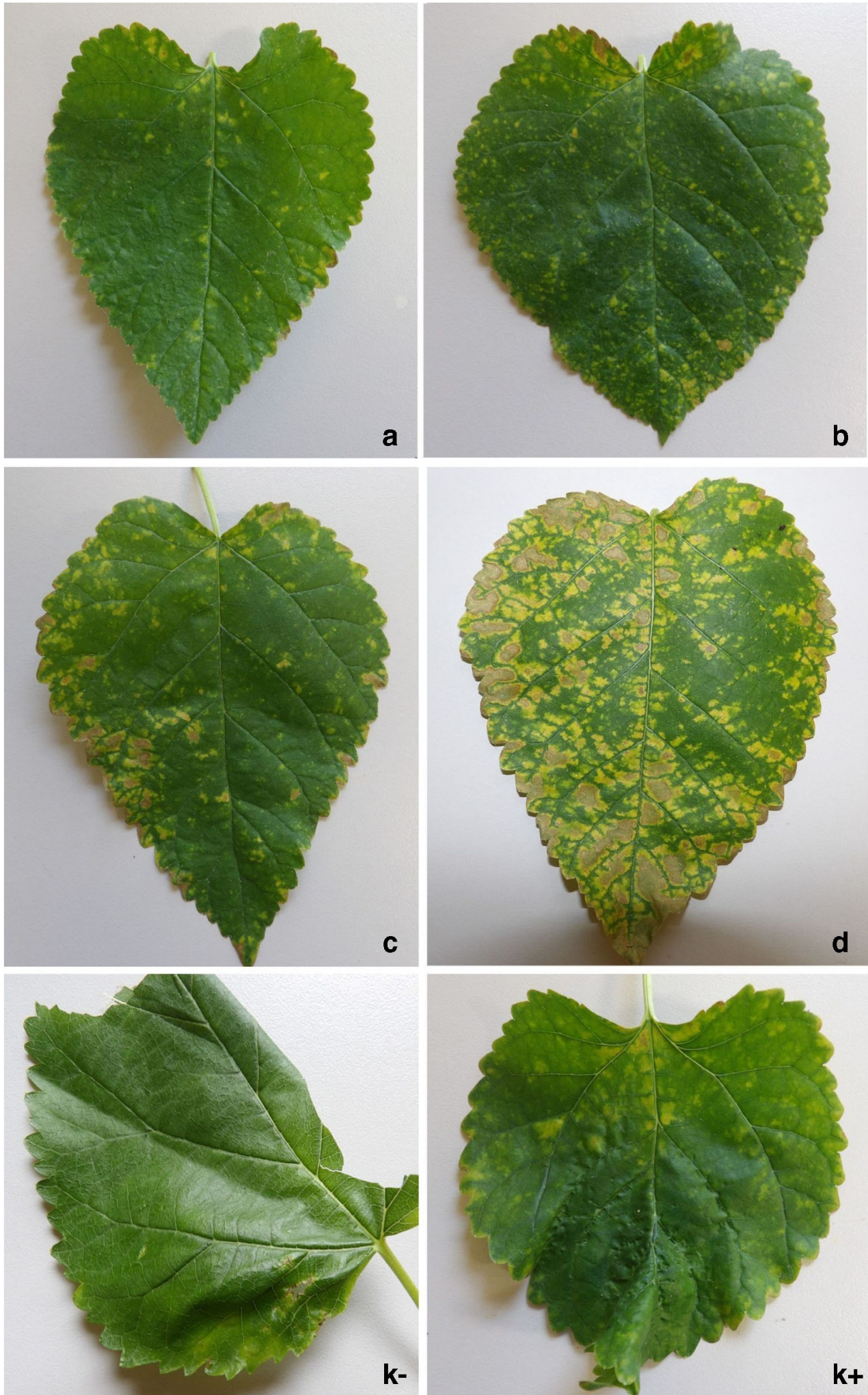

Fig. 4 Symptoms observed after spraying bacterial suspensions of Pseudomonas syringae on mulberry leaves. A-D - the pictures were aligned according to increasing symptoms development.

Negative control: leaves treated with sterile distilled water (K-); Positive control: leaves treated with the Pseudomonas syringae pv. syringae 2238 strain $(\mathrm{K}+)$ 
extracts of leaves of three Morus species (M. indica, M. latifolia, and $M$. laevigata) were tested to evaluate their antibacterial and antioxidant activity. Of the tested plants, the extracts of $M$. indica, and M. latifolia showed the highest antibacterial and antioxidant activity, and proved that the studied plant species are indeed important sources of pharmaceutical value (Joty et al. 2019). Nevertheless a specific plant protection compound based on those extracts is still not available commercially.

In summary, the studies we performed have proven P. syringae pv. mori to be the causal agent of mulberry bacterial blight in Poland. To our knowledge this is the first isolation, description and characterization of $P$. syringae affecting mulberry trees in Europe. This finding serves as a warning for phytosanitary services in Europe and for the sericulture industry that a new disease threat has appeared for the European mulberry crop.

Acknowledgements This paper was prepared as part of the project entitled: "Maintaining a unique Polish breeding of the mulberry silkworms varieties" financed by the Polish Ministry of Science and Higher Education (contract number 11/E-198/SPUB/SN/2019).

Funding information This study was supported by project no. 2014/13/B/NZ9/02108 from National Science Centre of Poland.

\section{Compliance with ethical standards}

Conflict of interest The authors declare that they have no conflict of interest.

Research involving human participants and/or animals Not applicable. The research involved no human participants or animals.

Informed consent The research involved no human participants, and no animals so that the statement on the welfare of animals is not required.

\footnotetext{
Open Access This article is licensed under a Creative Commons Attribution 4.0 International License, which permits use, sharing, adaptation, distribution and reproduction in any medium or format, as long as you give appropriate credit to the original author(s) and the source, provide a link to the Creative Commons licence, and indicate if changes were made. The images or other third party material in this article are included in the article's Creative Commons licence, unless indicated otherwise in a credit line to the material. If material is not included in the article's Creative Commons licence and your intended use is not permitted by statutory regulation or exceeds the permitted use, you will need to obtain permission directly from the copyright holder. To view a copy of this licence, visit http://creativecommons.org/licenses/by/4.0/.
}

\section{References}

Akhtar, M. A., \& Sarwar, M. (1988). Mulberry germplasm resistance to bacterial blight (Pseudomonas syringae pv. mori) in Pakistan. Trop. Pest Manag., 34, 227-228.

Arnold, D. L., \& Preston, G. M. (2019). Pseudomonas syringae: Enterprising epiphyte and stealthy parasite. Microbiol. (United Kingdom), 165, 251-253.

Baharuddin. (1997). Characteristics of Pseudomonas syringae pv. mori, Causal Agent of Bacterial Blight of Mulberry (Morus Spp.) in Indonesia. In ed. K. Rudolph. Kluwer Academic Publishers, p. 548-552.

Barbour, J. R., Read, R. A., and Barnes, R. L. 2008. MoraceaeMulberry family Morus L. mulberry. In Woody Plant Seed Manual, USDA, p. 728-732.

Bonasera, J. M., Asselin, J. E., \& Beer, S. V. (2014). Identification of bacteria pathogenic to or associated with onion (Allium сера) based on sequence differences in a portion of the conserved gyrase B gene. Journal of Microbiological Methods, 103, 138-143. https://doi.org/10.1016/j. mimet.2014.06.002.

Bultreys, A., \& Kaluzna, M. (2010). Bacterial cankers caused by Pseudomonas syringae on stone fruit species with special emphasis on the pathovars syringae and morsprunorum race 1 and race 2. Journal of Plant Pathology, 92, S1.21-S1.33.

Chairman, K., Singh, A. J. A. R., Amalarani, G., Padmalatha, C., \& Alagumuthu, G. (2012). Effect of marine extracts on the microbial pathogens causing flacherie in the mulberry silkworm. Bombyx mori L. Asian Pac. J. Trop. Biomed., 2, S1858-S1861.

Chen, K., \& Lu, Z. (2018). Immune responses to bacterial and fungal infections in the silkworm, Bombyx mori. Developmental and Comparative Immunology, 83, 3-11.

Chen, Y., Wang, J., Yang, N., Wen, Z., Sun, X., Chai, Y., et al. (2018). Wheat microbiome bacteria can reduce virulence of a plant pathogenic fungus by altering histone acetylation. Nature Communications, 9, 1-14.

Dai, Q., He, F. T., \& Liu, P. Y. (1997). Elimination of phytoplasma by stem culture from mulberry plants (Morus alba) with dwarf disease. Plant Pathology, 46, 56-61.

Dillon, M. M., Thakur, S., Almeida, R. N. D., Wang, P. W., Weir, B. S., \& Guttman, D. S. (2019). Recombination of ecologically and evolutionarily significant loci maintains genetic cohesion in the Pseudomonas syringae species complex. Genome Biology, 20, 1-28.

Edwards, U., Rogall, T., Helmut, B., Emde, M., Bottger, E., Blöcker, H., et al. (1989). Isolation and direct complete nucleotide determination of entire genes. Characterization of a gene coding for $16 \mathrm{~S}$ ribosomal RNA. Nucleic Acids Research, 17, 7843-7853.

EPPO Bulletin. (2006). Xanthomonas fragariae. EPPO Bulletin, 36, 135-144.

García-González, T., Sáenz-Hidalgo, H. K., Silva-Rojas, H. V., Morales-Nieto, C., Vancheva, T., Koebnik, R., \& ÁvilaQuezada, G. D. (2018). Enterobacter cloacae, an emerging plant-pathogenic bacterium affecting chili pepper seedlings. Plant Pathology Journal, 34, 1-10.

Gerischer, U. (2008). In U. Gerischer (Ed.), Acinetobacter molecular microbiology. Ulm: Caister Academic Press. 
Golding, C. G., Lamboo, L. L., Beniac, D. R., \& Booth, T. F. (2016). The scanning electron microscope in microbiology and diagnosis of infectious disease. Scientific Reports, 6, 1-8.

Gupta, V. P., Tewari, S. K., \& Datta, R. K. (1995). Surface Ultrastructural studies on ingress and establishment of Pseudomonas syringae pv. mori on mulberry leaves. Journal of Phytopathology, 143, 415-418.

Haeyoung, J., Kloepper, J. W., \& Ryu, C.-M. (2015). Genome Sequences of Pseudomonas amygdali pv . tabaci Strain ATCC. Genome Announcements, 1, 2-3.

Hinrichs-Berger, J. (2004). Epidemiology of Pseudomonas syringae pathovars associated with decline of plum trees in the southwest of Germany. Journal of Phytopathology, 152, 153-160.

Joty, F. A., Hasan, M. M. M., Khatun, R., Billah, M. M., Miah, M., Mahmud, S., et al. (2019). Evaluation of antibacterial and antioxidant activity of three plant species from Morus genus. Int. J. Biosci., 14, 183-189.

Kaluzna, M., Ferrante, P., Sobiczewski, P., \& Scortichini, M. (2010). Characterization and genetic diversity of Pseudomonas syringae from stone fruits and hazelnut using repetitive-PCR and MLST. Journal of Plant Pathology, 92, 781-787.

Kennely, M. M., Cazorla, F. M., \& Sundin, G. W. (2007). Pseudomonas syringae diseases of fruit Treen. Progress Toward Understanding and Control. Plant Disease, 91, 4 17.

Khezri, M., and Mohammadi, M. 2018. Identification and characterization of Pseudomonas syringae pv . syringae strains from various plants and geographical regions.

Korbie, D. J., \& Mattick, J. S. (2008). Touchdown PCR for increased specificity and sensitivity in PCR amplification. Nature Protocols, 3, 13-15.

Kumar, S., Stecher, G., Li, M., Knyaz, C., \& Tamura, K. (2018). MEGA X: Molecular evolutionary genetics analysis across computing platforms. Molecular Biology and Evolution, 35, $1547-1549$.
Lou, M. M., Jin, G. L., Tian, W. X., Zhang, G. Q., Fan, X. Y., Wang, F., Zhu, B., \& Xie, G. L. (2011). Specific and sensitive detection of Enterobacter mori using reliable RT-PCR. Plant Disease, 95, 1070-1074.

Mansfield, J., Genin, S., Magori, S., Citovsky, V., Sriariyanum, M., Ronald, P., et al. (2012). Top 10 plant pathogenic bacteria in molecular plant pathology. Molecular Plant Pathology, 13, 614-629.

Muthulakshmi, M., Devrajan, K., \& Jonathan, E. I. (2010). Biocontrol of root knot nematode, meloidogyne incognita (Kofoid and white) Chitwood in mulberry (Morus alba L.). Journal of Biopesticides, 3, 479-482.

Rahmathulla, V. K., \& Sathyanarayana, K. (2015). Influence of abiotic factors on population dynamics of major insect pests of mulberry. Pakistan J. Biol. Sci., 18, 215-223.

Sahin, F., Kotan, R., \& Dönmez, M. F. (1999). First report of bacterial blight of mulberries caused by Pseudomonas syringae pv. mori in the eastern Anatolia region of Turkey. Plant Disease, 83, 1176-1176.

Schaad, N. W., Jones, J. B., Chun, W., and others. 2001. Laboratory guide for the identification of plant pathogenic bacteria. American Phytopathological Society (APS Press).

Takahashi, K. (1980). The causal pathogen of bacterial blight of mulberry and its control. Jarq., 14, 41-45.

Wang, G. F., Praphat, K., Xie, G. L., Zhu, B., Li, B., Liu, B., \& Zhou, Q. (2008). Bacterial wilt of mulberry (Morus alba) caused by Enterobacter cloacae in China. Plant Disease, 92, 483.

Wulandari, Yasinta, Ratna, E., Yogiara, and Lizar, M. 2018. Detection of lectin gene ( MLL1 and M35 ) in mulberry plant ( Morus spp .) from Bogor, West Java, Indonesia. Biodiversitas. 19:2085-4722.

Yamamoto, S., Kasai, H., Arnold, D. L., Jackson, R. W., Vivian, A., \& Harayama, S. (2000). Phylogeny of the genus Pseudomonas: Intrageneric structure reconstructed from the nucleotide sequences of $g y r \mathrm{~B}$ and rpoD genes. Microbiology., 146, 2385-2394. 